\title{
Shared Pleasures and Strange Elisions: Three Types of Queer Ambiguity and 'Return-Migration' in Afrosporic Fiction
}

\begin{abstract}
In light of the emergence of African texts addressing same-sex desire as of the late 1970s, I examine three types of queer Afrosporic women's writing, i.e., Sky-High Flames (2005) by Nigerian, US-based Unoma Azuah; Cracks (1999) by South African, US-based Sheila Kohler; and The World Unseen (2001) by Shamim Sarif, born in the United Kingdom of African and Indian descent. These authors' characters are doubly diasporic on account of their queerness, complicated by two imaginative renditions of "return" - "return migration" and "ethnic return migration." Even if the passage from the sending society to the host society and the relocation in a Western country was voluntary, all three writers' imaginative return-migration involves some significant tension between the source and the target cultures, which is also verifiable in the authors' shuttling back and forth between sending and host society and in the canonical source subtexts that all three authors target to revisit or subvert. In examining how these authors' diasporicity impacted upon the representations of queer encounters, I also aim to show how this empowering representation of queer subjectivity and desire is fraught with elisions, which I deem strange given the authors' supposedly enabling displacement and relocation in the diasporic space.
\end{abstract}

In the wake of the emergence of African texts addressing same-sex desire as of the late 1970s, African diasporic or Afrosporic fiction started outlining a subtle move away from earlier concerns with establishing homosexuality as a lived experience contributing to shaping identity towards increased reciprocity in samesex relationships. Unlike early anthropological discourse, which tried to establish exclusive links between homosexuality and initiation rites, and unlike colonial discourse, which often documented unequal relations between partners (differences in age, social status, and pecuniary means), a growing number of Afrosporic literary texts project what Plutarch called charis. The term could be translated as what Michel Foucault called "la grâce,"1 referring to the love of boys, or, in English, "obligingness" or "gracious reciprocity" and, in a more recent legal discourse imbued with Human Rights vocabulary, as “consent."

My main focus is here on three types of queer Afrosporic women's writing: one that elides the desire; one that demonizes it; and one that represents it more directly and positively. The first of these is the Nigerian, US-based Unoma Azuah; the second, the South African, US-based Sheila Kohler; and, last, Shamim Sarif, born in the United Kingdom of South African and South Asian descent. Despite their elected exile and positioning, all three women writ-

1 Michel Foucault, Histoire de la sexualité: Le souci de soi (Paris: Gallimard, 1984): 242. 
ers have set their work in a resolutely African environment, in which homosexuality is criminalized and perceived gender dissidents are at risk of harassment, blackmail, extortion and even death. Even though African legislators and ordinary citizens continue to portray same-sex relationships as un-African and therefore inauthentic, the African continent is currently hosting a proliferation of nonconforming performances of gender and is ancestrally receptive to queer relational nexuses such as "female husbandry" or woman-woman marriages, even though none of the above writers acknowledge their existence. ${ }^{2}$

All three women writers - Azuah, Kohler, Sarif - have experienced displacement. Azuah left Nigeria for a combination of reasons, as she herself acknowledges, "because of the pressures of patriarchy as well as for a desire to further [her] studies abroad"; indeed, when she left in the mid-1990s, "the Nigerian educational system was in shambles due to constant closures of Universities due to political upheavals." ${ }^{3}$ We might add the adverse reactions to lesbian fiction such as that of Nigerian critic Oladele Taiwo, who famously proclaimed that "if tenable in Europe [lesbianism] has no chance of succeeding in Africa." South African Sheila Kohler also elected to go and live in the United States after studying in France while Shamim Sarif, although born in the United Kingdom, deals with diasporic subjects in her fiction.

Few scholars have studied how certain diasporic peoples have also been returning to their ethnic homelands. In his introduction to an edited book, Diasporic Homecomings: Ethnic Return Migration in Comparative Perspective (2009), Takeyuki Tsuda distinguishes between two types of diasporic return:

The first is the return migration of first-generation diasporic peoples who move back to their homeland (country of birth). The second is ethnic return migration, which refers to

2 See, among others, Joseph M. Carrier and Stephen O. Murray, "Woman-Woman Marriage in Africa," in Boy-Wives and Female Husbands: Studies in African Homosexualities, ed. Stephen O. Murray and William Roscoe (New York: Palgrave, 1998): 254-266; Denise O’Brien, "Female Husbands in Southern Bantu Societies," in Sexual Stratification: A Cross-Cultural View, ed. Alice Schlegel (New York: Columbia UP, 1977): 109-126. "Female husbands" are widows without a male offspring, who take on "wives" to produce heirs for their husbands' lineages. The "wives" then take on male lovers and have children who are in turn handed over to the "female husbands." The first study to show awareness of gender bending in Nigerian female husbandry was British anthropologist Sylvia Leith-Ross, African Women: A Study of the Ibo of Nigeria (London: Faber \& Faber, 1939). Leith-Ross was, however, unfairly dismissed as a "racist" by Nigerian anthropologist Ifi Amadiume in Male Daughters, Female Husbands: Gender and Sex in an African Society (London, New Jersey: Zed Books, 1987).

3 Unoma Azuah, personal communication by email, 25 May 2010.

4 Oladele Taiwo, Female Novelists of Modern Africa (London: Macmillan, 1984): 24. 
later-generation descendants of diasporic peoples who "return" to their countries of ancestral origin after living outside their ethnic homelands for generations. ${ }^{5}$

To these two types of "return" - "return migration" and "ethnic return migration," also called "ethnic affinity migration" - , one could add the imaginative and imaginary return to the homeland, e.g., Nigeria in the case of Unoma Azuah and South Africa in the case of Sheila Kohler or Shamim Sarif. They have, in a sense, "return-migrated" through literature, which does not exclude the return to the migrant-sending society or the physical shuttling back and forth between the migrant-receiving country and the migrant-sending country, for instance, in Unoma Azuah's case, her going back and forth between the United States and Nigeria.

Unoma Azuah is one of the most vocal of West-African-born lesbian-identified authors. In a 2005 contribution, Azuah theorized her work for the first time and presented it as part of a Nigerian lesbian continuum that comprises her Nigerian "sisters" back home like Promise Okekwe and Temilola Abioye. ${ }^{6}$ She has focused on desiring women in her debut novel Sky-High Flames (2005) but more resolutely in her poetry as in the collection Night Songs (2001), in which a new brand of Afrosporic feminism is making room for the material and discursive factors that act together to define what it is to be a lesbian. ${ }^{7}$

5 Takeyuki Tsuda, "Introduction: Diasporic Return and Migration Studies," in Diasporic Homecomings: Ethnic Return Migration in Comparative Perspective, ed. Takeyuki Tsuda (Stanford: Stanford UP, 2009): 1-21, 1.

6 Unoma Azuah, "The Emerging Lesbian Voice in Nigerian Feminist Literature," in Body, Sexuality, and Gender: Versions and Subversions in African Literatures, eds. Flora Veit-Wild, Dirk Naguschewski (Amsterdam, New York: Rodopi, 2005): 129-142, 130. In Promise Okekwe's novel Women from the Crystal Deep (2002), Rebecca's lesbian leanings are stigmatized as being unnatural and evil desires, and in Temilola Abioye's story "Taboo," Oyinkan daringly suggests in the midst of a conversation with four women: "Why don't we all take a shower and go down on each other. It wouldn't be copulating, it would be a lot of petting, smooching and caring” (qtd. in Azuah, “The Emerging Lesbian Voice,” 130). Azuah also discusses her own short story, "The Rebel," in which a woman suffers because of her sexual orientation and ultimately loses her lover to a monastery, as well as her own poem "Onishe," named after the Nigerian feminine deity revered in her novel Sky-High Flames.

7 As Azuah herself admitted in an interview, fiction is her "wife" and poetry her "mistress" (in Azuonye Nnorom, “Interview with Unoma Azuah," Sentinel Poetry Quarterly 4 [2005], n.p.). The somewhat illicit status of poetry as a "mistress" rather than a "wife" has enabled Azuah to provide what I call the "stuff of desire" by celebrating lesbian bonding. It is thus the form that dictated her approach in sketching same-sex love between Nigerian women. I discuss Azuah's poetry in relation to her prose narratives in my Out in Africa: Same-Sex Desire in Sub-Saharan 
Set in Igboland in the 1970s, Sky-High Flames chronicles the life of Ofunne, who overcomes "sky-high flames," fanned mostly by aggressive men, before attaining self-realization. The first daughter of an Igbo polygamous household, Ofunne queers the general distribution of sex roles. Such initial transgressions are later comforted through what I have called furtive, flash-like "moments of intimacy," after Virginia Woolf's "moments of being," with women such as her childhood friend and the European Reverend Sister at the Teachers' Training College. Such moments of intimacy are imbued with "the beauty and libidinality of transgression," as South African exile Bloke Modisane eloquently put it in another context. ${ }^{9}$ Nevertheless, what may be argued is "missing" in the novel set in an exclusive girls' school where girls sleep in communal dormitories and are expected to take baths in "an open wide bathroom"10 is homosociality and sexuality, as if desire had been excised from the narrative. The boarding schoolgirls are, however, not completely unaware of the fluidity of shifting performance. Physical intimacy between young and older women is discursively confined to the flogging that teachers inflict upon students but without any mention of the psychological consequences of corporal punishment, let alone the girls' recuperation of flogging in sadomasochistic or fetishistic terms.

The confessional scenario by proxy (Azuah providing a first-person narrative with Ofunne as main narrator while telling the story of her real-life aunt 'Asua) suggests, as I have argued elsewhere, ${ }^{11}$ an allegory of sexual self-discovery, which deviates into fiction, as indeed all sexuality does, since it inevitably rests on unconscious, infantile-determined scenarios of fulfillment. Azuah is in the same position as John in J. M. Coetzee's Youth (2003), confronted with the violence of the archive of her (and her aunt's) past; in order to bring off the narrative, she "will need to know less than [she] knows now, and [she] will need to forget things."

The boarding school, seething as it does with pubescent sexuality, can easily conjure up the idea of "situational homosexuality." This has been applied by

Literatures and Cultures (Woodbridge, Suffolk; Rochester, NY: Boydell and Brewer/James Currey, 2013): 147-149.

8 Cf. Virginia Woolf, Moments of Being: Unpublished Autobiographical Writings, ed. Jeanne Schulkind (London: Chatto and Windus, 1976): 221.

9 Bloke Modisane, Blame Me on History [1963] (New York: Simon and Shuster, 1990): 299. 10 Unoma Azuah, Sky-High Flames (Baltimore: PublishAmerica, 2005): 39. Further references in the text, abbreviated as "SHF."

11 Chantal Zabus, "Of Female Husbands and Boarding School Girls: Gender Bending in Unoma Azuah's Fiction,” Research in African Literatures 39.1 (2008): 93-107.

12 J. M. Coetzee, Youth (London: Vintage, 2003): 138-139. 
Robert Aldrich in Colonialism and Homosexuality (2003) to unequal power relations between colonials and natives, and by T. Dunbar Moodie to South African "mine-marriages," that is, initiatory and intergenerational relations between "hubbies" (indunas) and "boy-wives" (tinkonkana, skesanas) in Bantu-speaking, all-male, mining complexes. ${ }^{13}$ Yet, the notion of circumstantial homosexuality in a West African context does not do justice to, for instance, supis in Ghanaian boarding schools, that is, girls who participate in sexual activities with their girl partners in secrecy (it is called a pash) until one party denounces the other. ${ }^{14}$ Most pashes are, however, over before reaching even "this innocent stage" and suggest that the schoolgirl's "crush" is a necessary prelude to the "serious business" of adult heterosexuality.

American girls' comic and teenage magazines as well as girls' boarding school stories host a similar script of sexual self-discovery in both homosexual girls and heterosexual girls, who experienced the same "lesbian" feelings but never questioned their status as heterosexual. Same-sex attraction among girls therefore materializes as "lesbianism" when sexual identity develops from a "pre-given state, waiting to be discovered or expressed." 15 The boarding-school situation therefore provides the matrix where that "pre-given state" may be "expressed" and that expression is made flesh in "doing lesbian," which is, according to Jane M. Ussher, "something that women do, rather than something they are."16 Similarly, female husbands and their women mates may find an expression of their mutual attraction within the institution of female husbandry but this does not mean that all female husbands are lesbians and "doing lesbian."

What is adumbrated in Azuah's narrative is the shifting of the various subject positions of being, doing, resisting or subverting "girl" by being a "tomboy," as in the scene in which Ofunne takes up the virile role by protecting her (female) childhood friend from boys' intimidations in the River Niger ( $S H F$,

13 Robert Aldrich, Colonialism and Homosexuality (London, New York: Routledge, 2003); and T. Dunbar Moodie, "Migrancy and Male Sexuality on the South African Gold Mines" in Hidden from History: Reclaiming the Gay and Lesbian Past, eds. Martin Duberman, Martha Vicinus and George Chauncey (New York: Meridian, 1989): 411-425.

14 Angela Lambert, No Talking After Lights (London: Penguin, 1991): 99. Lambert mentions that, in British boarding schools, a "pash" can indeed develop "between a pretty junior and a receptive senior [that] might lead to a secret meeting in the long grass at the end of the games field."

15 Jane M. Ussher, "Framing the Sexual 'Other': The Regulation of Lesbian and Gay Sexuality," in Body Talk. The Material and Discursive Regulation of Sexuality, Madness and Reproduction, ed. Jane M. Ussher (London, New York: Routledge, 1997): 131-158, 149. See also Jane M. Ussher, Fantasies of Femininity: Reframing the Boundaries of Sex (London: Penguin, 1997).

16 Ussher, "Framing the Sexual 'Other'," 150. 
26-27). But Azuah has chosen not to give narrative space to the boarding schoolgirls' "doing lesbian" and has thus been resistant to allow their sexuality to develop as a set of repeated performances in a Butlerian sense. ${ }^{17}$ Desire is here carefully sanitized, leaving one to wonder why Azuah allowed the potential feminine amitiés particulières to be dulled by the college's monotonous routine of meals, siestas, afternoon preps and prayers. The novel seems to endorse the stereotype that if lesbianism exists, it is just a "passing thing." However, since Azuah is writing about her aunt or, rather, is writing her own story by proxy, this debut novel may be considered as being traversed by the partially told story of Azuah's aunt and the as yet untold story of Azuah growing up as a lesbian girl-child in Nigeria.

Elsewhere, on the West African scene, both Ghanaian writer Ama Ata Aidoo in Our Sister Killjoy (1977) and Nigerian Lola Shoneyin in her short story "Woman in Her Season" (1997) deal with interracial lesbian relations: between a Ghanaian woman and a German one, and between a Nigerian woman and a Swiss one. They can, however, only imagine lesbian love between a black and a white woman in Europe, as if the lesbian partner could only be a (Northern) European and never a consenting Nigerian (or African) woman. ${ }^{18}$ But Aidoo, who is not lesbian-identified and has denied dealing with a lesbian theme in Our Sister Killjoy, ${ }^{19}$ and Shoneyin, who is lesbian-identified, are both writing from their African platform, where queer practices are generally construed as a deviant import from the West, or psychological aberrations that would require a cure and, in some cases, rehabilitation in a camp. ${ }^{20}$ In any case, it is vociferously criminalized. As a case in point, Nigerian President Goodluck Jonathan has in January 2014

17 I am here referring to Judith Butler's Foucauldian analysis of performativity in her Gender Trouble: Feminism and the Subversion of Identity (New York, London: Routledge, 1999): 171 -190 .

18 Same-sex sexuality between African women has, however, been documented, even in the distant past. The seventeenth-century (1672) Ethiopian book The Life and Struggles of Our Mother Wälättä Peggle (Gädlä Wälättä Peothe in the Glə^nəz language) features a life-long partnership between two Ethiopian women and the depiction of same-sex sexuality among nuns.

19 "All I have to say is that I have not dealt with lesbianism at all on a conscious level though I know it is in the story. I know that in certain girls' schools there is something there, but in the Ghanaian society everybody comes out of the boarding schools and he or she is a properly heterosexual being. [...] Everybody comes out and is a very respectful heterosexual being: we marry, we have children, we carry on with our lives" (in Maria Frías, "An Interview with Ama Ata Aidoo: 'I learnt my First Feminist Lessons in Africa'," Revistas Estudios Ingleses 16 [2003]: 6-53, 38 $-39)$.

20 This is the case of a Mozambican woman, qtd. in Adrienne Rich’s seminal essay, "Compulsory Heterosexuality and Lesbian Existence," in The Lesbian and Gay Studies Reader, eds. Henry Abelove, Michele Aina Barale and David Halperin (London: Routledge, 1993): 227-254, 240. 
signed a bill outlawing same-sex relationships and sentencing sexual dissidents to imprisonment for up to fourteen years. ${ }^{21}$

By contrast, Cracks (1999) by American-based, South African Sheila Kohler goes to the opposite extreme of Azuah's Sky-High Flames in making the headmistress Miss $G$ the abusive lover of one of her wards and in entrenching the idea that lesbianism is a ritualistic phase before accessing early adulthood. Cracks, which was made into a movie (2009), is an anxiety-ridden autobiographycum-thriller which ghosts apartheid policies as twelve adults, who spent their formative years at an English school in the South African veld, hold a school reunion in the post-apartheid era under the aegis of the former school Principal. "Sheila" is one of the thirteen girls on Miss G's swimming team and has the same name as the author; yet the author, Sheila Kohler, has never acknowledged that her fiction is infused with autobiographical material, ${ }^{22}$ even though she openly admits on her personal website that her sister's violent death during apartheid in circumstances that are not revealed to the reader haunts all of her writing. ${ }^{23}$ Overall, the novel reads like the confession of a collective secret guilt concerning the thirteenth girl who joined Miss G's swimming set, Fiamma Coronna, the Roman Catholic "Crowned Flame” or "crush" from Italy.

Kohler's novel title is explained in an early subchapter's question - "What are Cracks?" - to which the omniscient narrator's answer is "Miss G was our crack" $(C, 26)$ while conjuring up the colloquial term for vagina. But the "cracks" are also the narrative cracks and crannies of which the reader gets voyeuristic glimpses, as through a confessional's grille. The world of "cracks" is the impressionable, highly emotive sphere of budding adolescent sexuality, which is here exacerbated by the girls' forced separation from their English mothers. Kohler

21 Felix Onuah, "Nigerian Leader Signs Anti-Gay Law, Drawing U.S. Fire” (January 13, 2014), Reuters <http://www.reuters.com/article/2014/01/13/us-nigeria-gay-idUS BREA0C10820140113> (acc. February 28, 2014).

22 There is one passing reference to the character Sheila Kohler's early thwarted ambitions "to be a writer like Alan Paton [...] but she has only written thrillers, all of them about murdered girls" (Sheila Kohler, Cracks [1999] [London: Bloomsbury, 2002]: 98; further references in the text, abbreviated as " $C$ ").

23 "When my sister died a violent death thirty years ago in apartheid South Africa, my writing took a new turn. I was driven to explore the reasons for violence within intimate relationships, in particular, the abuse of power and privilege. Since then I have published nine novels, three collections of short stories, and several others not yet collected, all of which focus in some way on this theme. They represent my attempt to delve into the mysteries of hate and anger, and of love and compassion, as well. I am hoping that you will share them with me" (Sheila Kohler, qtd. on "Welcome to the Official Site for Sheila Kohler" [2009-2014] Sheila Kohler <http://www.shei lakohler.com> [acc. March 1, 2014]). 
ingeniously orchestrates Miss G's decline, as the iconoclastic swim teacher, smitten with Fiamma, becomes distracted and loses weight. Her neglected girls consequently ask Fiamma to "be sweeter to Miss G" and "sacrifice [herself] for the common good" $(C, 93)$ to appease the female horde; but this culminates in her murder. During one outing in the veld under the supervision of Miss G, the girls frantically insert sticks into the asthmatic child's orifices and gag her until she dies of asphyxia. They subsequently lay down Fiamma's corpse along the Boer War hero Sir George's remains inside his tomb, burying their secret until the time of the school reunion several decades later, in post-apartheid Africa.

The role of Miss $G$ in this act of teenage tribalism, which recalls William Golding's Lord of the Flies, is not at all clear, but she seems not to have known about Fiamma's ultimate fate. ${ }^{24}$ Yet, she remains a facilitator of sorts, for she seals a butch pact with an older girl, Di Radfield, who ends up being the vengeful murderer of Miss G's femme by proxy. Short of writing out of homophobia, Kohler's incomplete sketch of the consensual relation between Miss G and Di Radfield finds a disturbing corollary in her eliding of race - there are no Black or Coloured characters in the text. Such an elision, which seems logical given the context of an all-white school in the apartheid era, is unsettling when one considers the almost intangible presence of one Black helper in the boarding school as a form of tokenism and of gesturing towards race as a displacement for the white woman's burden of general guilt. Kohler's fictional surrogate, "Sheila," acknowledges her role in Fiamma's death but it is somewhat played down and shrouded in her love of fiction, the constant pull of which continuously deters the reader from reading Cracks as a repentant autobiography delivered to the readership of a fictive South African Truth and Reconciliation Commission.

Kohler's relocation in France in 1958 and then in the United States in 1981 has not helped shed such psychological hang-ups but has instead vitiated memorial rehearsals of her return to the native land, thereby leaving wounds to fes-

24 I here differ from Cheryl Stobie's reading in "Between the Arches of Queer Desire and Race: Representing Bisexual Bodies in the Rainbow Nation,” in Body, Sexuality, and Gender: Versions and Subversions in African Literatures, eds. Flora Veit-Wild, Dirk Naguschewski (Amsterdam, New York: Rodopi, 2005): 66-87. Taking her cue from Marjorie Garber (in Vice Versa [London: Penguin, 2007]), Cheryl Stobie applies a bisexual epistemology to post-apartheid novels in the South African "Rainbow Nation" and casts Miss G as a bisexual individual whose paedophile abuse and rape of Fiamma helps demonize her boundary-crossing. Such a reading indeed occludes the fact that Miss G is primarily a lesbian rather than a bisexual individual and, beyond bisexuality, the novel leaves little room for "wasbians," "maybians," and other interstitial ways of being sexual. 
ter as in the unclaimed experience of trauma. Moreover, the older women's act of ritual cleansing in the post-apartheid plot of the novel - swimming, naked, down the river - may alleviate their guilt, but Fiamma's ritual murder is left unpunished. Even though Kohler may be said to have "gather[ed] the past in a ritual of revival," as Homi K. Bhabha put it in another context, ${ }^{25}$ the healing ritual remains Kohler's surrogate's private exorcism. "Sheila" is thus stuck between an impasse and melancholia, blockage and mourning, two opposite stances limned in postcolonial and diaspora theory. ${ }^{26}$ Kohler's stance as well as the persistent haunting memory of her sister's death also illustrate the grief and pain of living in diaspora, which Ahmad Aijaz and Benita Parry have emphasized in an effort to balance out the somewhat optimistic celebration of exile by Salman Rushdie or Edward Said. ${ }^{27}$

Significantly, Cracks was published in the aftermath of the new South African Constitution and the implementation of its 1996 Bill of Rights including its 9:3 clause granting people "the right to equality before the law and freedom from discrimination. Prohibited grounds of discrimination include race, gender, sex, pregnancy, marital status, ethnic or social origin, colour, sexual orientation, age, disability, religion, conscience, belief, culture, language and birth." 28 But the South Africa Kohler revisits in Cracks is not the Rainbow nation or the first country in the world to constitutionally prohibit discrimination based on sexual orientation but rather apartheid South Africa, shortly after the official beginning of the infamous regime in 1948, with its Immorality or Sexual Offences Acts, which were obsessively repealed and renamed.

The return of the repressed - race - occurs in Shamim Sarif's The World Unseen (2001). The novel breaks new ground in depicting an interracial same-sex attraction in South Africa in the 1950s, the same time period as in Cracks. The novel is definitely set in a queer place and time, to borrow Judith (Jack) Halberstam's book title, ${ }^{29}$ as it is set against the tormented canvas of the 1946 Indian

25 Homi K. Bhabha, The Location of Culture (London: Routledge, 1994): 139.

26 Cf. Eleanor Byrne, "Diasporic Literature and Theory, Where Now? Passing Through the Impasse," in Diasporic Literature and Theory - Where Now?, ed. Mark Shackleton (Newcastleupon-Tyne: Cambridge Scholars P, 2008): 18-34.

27 Cf., for instance, Ahmad Aijaz, In Theory: Classes, Nation, Literature [1992] (New Delhi: Oxford UP, 2001); and Laura Chrisman and Benita Parry (eds.), Postcolonial Theory and Criticism (London: D. S. Brewer, 2002).

28 Constitution of the Republic of South Africa (1996), s. 9(3), see <http://www.gov.za/sites/ www.gov.za/files/images/a108-96.pdf> (acc. March 10, 2015).

29 Judith Halberstam, In a Queer Time and Place: Transgender Bodies, Subcultural Lives (New York, London: New York UP, 2005). 
Congress protests against the Ghetto Bill, the 1949 Mixed Marriages Act, and the Group Areas Act.

The World Unseen, which novelist and film director Sarif made into a movie in 2007, sketches a relationship between two women, Amina, a lesbian-identified local girl, and Miriam, raised in Bombay and trapped in a loveless marriage of convenience in forlorn Delhof, South Africa. Against a background of miscegenation, bi-racial rape, and unresolved tensions, the growing intimacy between the two women is sealed in Miriam's garden, a prelapsarian space where genesis can start all over again. After a scene of sweaty eroticism "in the rising heat," ${ }^{30}$ Sarif benevolently follows Miriam's gradual shedding of all past relics before she propels her into her diasporic and disjunctive present. There is a faint hint at the novel's closure that Miriam and Amina will "do lesbian" and continue some sort of relationship, yet suspended, queer.

Shamim Sarif takes the romance to its sulfurous conclusion in her third, semi-autobiographical novel, I Can't Think Straight (2007), which she also brought to the screen, and in which a young Palestinian Christian bride, Leila, patterned after Sarif's partner Hanan Kattan, falls in love with Sarif's alter ego, Tala, a young British Muslim woman of Indian descent. The happy ending is, of course, possible and more plausible in London, where the two young women can enact their mutual attraction, than in Pretoria in the 1950s, where the bi-racial lesbian affair is doomed to failure or at any rate secrecy. Amina and Miriam's relationship in The World Unseen will indeed thrive in secret; yet it is, paradoxically, apartheid South Africa which provides Amina, a diasporic subject, with insights into her queer desire. Likewise, Miss G, who is the one truly diasporic queer subject in Cracks, comes from Wales and flees to South Africa under mysterious circumstances, which Kohler does not explore. It is, however, intimated that she can enact her queerness in that particular enclave in the South African veld until she is betrayed by her own and, as a result, loses her job, goes derelict, and is sacrificed for a common good that is ultimately obscure.

The South African context, especially under the post-apartheid Constitution, with its debates on Human Rights, sexuality and accountability, offers an excellent terrain for testing queer theory. Retrospectively, the apartheid period also provides such a theoretical testing ground, precisely because homosexual bonding, like interracial love, let alone interracial queer relations, was criminalized and the African National Congress's developments toward democratization

30 Shamim Sarif, The World Unseen (London: Women’s P, 2001): 118. Further references in the text, abbreviated "WU." 
had not yet helped create new spaces of queer visibility. ${ }^{31}$ The "world" of desiring women was, in Sarif's words, "unseen," but by documenting highly charged, volitional same-sex relationships, both her novel and her movie help excavate one more layer of lesbian history from what Ann Cvetkovitch has called an "ephemeral transnational archive." 32

Besides pulling the trigger of queer visibility, Sarif also connects two women, one Indian and one South African of Indian and African descent, in an attempt to make sense out of her own double belonging through her parents' background. Even though Amina has black blood from her grandmother's rape by her husband's African employee back in 1892, she is construed as Indian and Coloured under apartheid. Like West African writers Ama Ata Aidoo and Lola Shoneyin, who could not or would not imagine a lesbian affair between two African women, Sarif did not imagine or did not dare imagine a relationship between an Indian-born woman and a Black South African woman, let alone between a Coloured and a Black woman under apartheid. This relative elision, validated by the novel's semi-autobiographical vestment and evened off by Amina's touch of the tar brush, entails that the Afrosporic novel practices its own politics of inclusion and exclusion, which reflects in turn other exclusions in diaspora theory. ${ }^{33}$

All three women writers - Unoma Azuah, Sheila Kohler, Shamim Sarif have experienced exile but a chosen exile, which may at first disqualify them from being described as truly diasporic. In the theoretical conjectures on diaspora of e.g., Robin Cohen, William Safran, Khachig Tölölyan, and Nicholas Van Hear, diaspora is often assimilated to the territorial dispersal of ethnic groups across different nations because of ethnopolitical or economic reasons. Such groups, always conceived in their plural form, retain a sense of attachment to the "ethnic homeland" of origin..$^{34}$ This definition of diaspora is, however, based on the notion of exile since for the diasporic individuals, the ethnic homeland "remains a distant place of nostalgic longing to which they cannot re-

31 I discuss "Interracial Queer Relations" at more length in my Out in Africa, 207-216.

32 Ann Cvetkovitch, An Archive of Feelings. Trauma, Sexuality and Lesbian Public Cultures (Durham, NC: Duke UP, 2003): 1.

33 Cf. Swaraj Raj, "Problematics of Theorizing Diaspora and Situating Diaspora Literature," in Contemporary Diasporic Literature: Writing History, Culture, Self, ed. Manjit Inder Singh (Delhi: Pencraft International, 2007): 49-60, 49.

34 See Robin Cohen, Global Diasporas: An Introduction (Seattle: U of Washington P, 1997); William Safran, “Diasporas in Modern Societies: Myths of Homeland and Return," Diaspora: A Journal of Transnational Studies 1.1 (1991): 83-99; Khachig Tölölyan, "Rethinking Diaspora(s): Stateless Power in the Transnational Moment," Diaspora: A Journal of Transnational Studies 5.1 (1996): 3-36; Nicholas Van Hear, New Diasporas: The Mass Exodus, Dispersal, and Regrouping of Migrant Communities (Seattle: U of Washington P, 1998). 
turn." ${ }^{35}$ Exile and diaspora therefore overlap. A case in point is Bessie Head, who, presumably because of her pan-African political activities, never envisaged returning to the South African homeland that she deliberately left to relocate in Botswana. In her autobiographical A Woman Alone, she describes her exile in Botswana from 1964 to 1979, after which date she became a full-fledged citizen, ${ }^{36}$ whereas Lloyd Wesley Brown lists Head under "Diaspora" in his Women Writers in Black Africa (1981). ${ }^{37}$ For her part, as already argued, Sheila Kohler elected exile in the United States but frequently returns to South Africa; and Shamim Sarif, although born in the United Kingdom, deals with diasporic subjects in her fiction and in her movies. Yet, these authors write from the perspective of a (post)colonial position rather than from a victim or economic diasporic position.

All three writers do not wish to "return" to the ethnic homeland, the way first-generation diasporic peoples move back to their country of birth after experiencing migration. As a second-generation descendant of South African diasporic parents, Shamim Sarif has not expressed the desire to "return-migrate" to the birth country of her Indian (grand-)parents; in other words, there is no "ethnic return migration" or "ethnic affinity migration," in the sense in which Takeyudi Tsuda has envisaged the different types of diasporic homecoming. The "return" to the homeland is imaginative and is enacted through literature. Instead of conceiving of the diasporic individual as moving from a migrant-sending society to a migrant-receiving country like England or the United States in a unipolar or oneway process, it is more fruitful to envisage a bipolar or even a multipolar flow or migratory dispersal. The works of such women writers allow for at least the bipolar flow of literature.

In their elected dispersal, these authors' characters inhabit the uneasy "cracks" of the hosting cultures - between India and South Africa, between the United States and South Africa, between South Africa, India, and the United Kingdom. But the characters are also doubly diasporic on account of their queerness, which is to heterosexuality what the diasporic state is to the notion of "home." At the same time, these characters' desire is, with a cautionary tale attached to Kohler's fictional surrogate, forward-looking and proves Gayatri Gopi-

35 James Clifford, “Diasporas,” Cultural Anthropology 9.3 (1994): 302-338, 304.

36 Bessie Head, A Woman Alone: Autobiographical Writings, ed. Craig McKenzie (London: Heinemann, 1990): 11.

37 Lloyd Wesley Brown, Women Writers in Black Africa (Westport, CT: Greenwood P, 1981): 158 -179 . 
nath right when she holds that "queer desire reorients the traditionally backward-looking glance of diaspora." 38

Even if the passage from the sending society to the host society and the relocation in a Western country was voluntary, all three writers' "return" or "passage," here understood in a loosely psychological sense, involved "some significant tension between the source and the target cultures." 39 Tellingly, the authors' shuttling back and forth between sending and host society or target and source cultures is also verifiable in the canonical source subtexts that all three authors target to revisit or subvert. Each text under scrutiny contains in filigree references, embedded allusions to, and at times extensive rewritings of, mainstream, first-world texts, Jane Eyre being among the favorites, which is confirmed by Sheila Kohler's 2009 eponymous novel Becoming Jane Eyre.

Miss G's name in Cracks conjures up the unconventional Miss Jean Brodie in Muriel Spark's 1961 novel. There is more to it than mere homonymy since, upon the publication of Cracks, Books Magazine called Kohler's novel "[m]ore sinister and sexual than The Prime of Miss Jean Brodie." 40 Miss G follows the same trajectory as Miss Brodie but her queerness is moved several notches higher. Her shady Welsh past, her dark-eyed slim athletic appearance and dark hair, "as glossy as a gypsy's" $(C, 31)$ recalls the dubious origins and swarthy looks of Heathcliff. Significantly, the Brontë subtext, specifically that of Jane Eyre and of Wuthering Heights, is queered in the process, for Heathcliff is revisited as butch and Jane Eyre is imagined as having an affair with Miss Temple through the subdued relationship between Miss G and her pupil "Reckless [Di] Radfield" to whom, however, Miss G recommends reading "not The Tempest or Jane Eyre" but D. H. Lawrence $(C, 34)$. In Shamim Sarif's The World Unseen, among the fifteen books stored in her cellar since her departure from Bombay, Miriam singles out “[Thomas Hardy's] Far from the Madding Crowd and Jane Eyre” (WU, 222) but settles finally on Louisa May Alcott's Little Women, for she had, as a girl, "always imagined herself as the fiery, independent character Jo March, but when she thought about it now, it was someone else that she pictured in that role" (WU, 225). The tomboy Jo March in Alcott's novel also reflects on the male "switch" character, Laurie, in the plot development. Laurie is the next-door neighbor who has spent years wooing Jo March and, who, after she rebuffed him, simply married Jo's kid sister, Amy, on the rebound. In a chiasm of sorts, Miriam reluctantly contracts a marriage of convenience in India to then embark, once in

38 Gayatri Gopinath, Impossible Desires: Queer Diasporas and South Asian Public Cultures (Durham, London: Duke UP, 2005): 3.

39 Makarand Paranjape, In Diaspora (New Delhi: Indialog, 2001): 6.

40 Kohler, Cracks, backcover blurb. 
South Africa, on a loving relationship with the tomboy Jo March-like Amina, whom she had first identified with.

Even though they have markedly different agendas, both Kohler and Sarif inflect and queer the canonical texts to suit their characters' sexual dissidence and, in destabilizing the source-target cathexis, they help shift and reshuffle priorities in the circulation of knowledge. Also, in staging a growing sense of reciprocity and relationality and in covering a spectrum of marginal sexualities and of ethnic minorities (Black, Coloured, Indian) under apartheid, Afrosporic women writers have contributed to locating "queer times and places," that is, queer temporal and spatial niches in repressive systems. In so doing, Afrosporic women writers share a larger diasporic space, which can host female queerness while they point to aporias and exclusions. I deem these elisions "strange," given the authors' supposedly enabling displacement and relocation in the diasporic space.

Such exclusions therefore reveal the continued inadequacy of contemporary diaspora theory while pointing to what we hope will be curious and curiouser attempts to portray shared pleasures and charis between African women at "home." Kagure Mugo, a UK-trained Kikuyu young woman studying at the University of Cape Town and a member of HOLAA!, a pan-African site publishing the work of queer women, seems to show the way. In a letter to her parents in her native Kenya, she writes:

Replace the spectrum of

Everything I was and replace it

with a single identity.

Gay. ${ }^{41}$

“A Little Longer," is, however, written from a diasporic location, post-apartheid South Africa, and is a plea for the revelation of her "gayness" to her parents to be postponed while she waits "a little longer." It remains to be seen whether the African "home" rather than its diasporic counterpart can truly host same-sex desire for both men and women in African nation-states.

41 Kagure Mugo, “A Little Longer: A Plea for Full Existence,” Q-Zine 6 (2013): 76-81, 76. Accessible via ISSUU <http://issuu.com/q-zine/docs/qz6e> (acc. March 2, 2014). 